\title{
Defenders and Critics of Franciscan Life. Essays in Honor of John V. Fleming, Edited by Michael F. Cusato \& G. Geltner
}

\section{G. Matteo Roccati}

\section{(2) OpenEdition}

Journals

\section{Édition électronique}

URL : http://journals.openedition.org/studifrancesi/3654

DOI : 10.4000/studifrancesi.3654

ISSN : 2421-5856

Éditeur

Rosenberg \& Sellier

\section{Édition imprimée}

Date de publication : 1 décembre 2012

Pagination : 544

ISSN : 0039-2944

\section{Référence électronique}

G. Matteo Roccati, «Defenders and Critics of Franciscan Life. Essays in Honor of John V. Fleming, Edited by Michael F. Cusato \& G. Geltner », Studi Francesi [En ligne], 168 (LVI | III) | 2012, mis en ligne le 30 novembre 2015, consulté le 07 mars 2021. URL : http://journals.openedition.org/studifrancesi/3654 DOI : https://doi.org/10.4000/studifrancesi.3654

Ce document a été généré automatiquement le 7 mars 2021.

\section{cc) (†) $\odot$}

Studi Francesi è distribuita con Licenza Creative Commons Attribuzione - Non commerciale - Non opere derivate 4.0 Internazionale. 


\title{
Defenders and Critics of Franciscan Life. Essays in Honor of John V. Fleming, Edited by Michael F. Cusato \& G. Geltner
}

\author{
G. Matteo Roccati
}

\section{RÉFÉRENCE}

Defenders and Critics of Franciscan Life. Essays in Honor of John V. Fleming, Edited by Michael F. CUSATO \& G. GELTNER, Leiden - Boston, Brill, 2009 («The Medieval Franciscans», 6), pp. XVI-254.

1 L'introduction nuance le libellé du titre, les critiques les plus dures des Franciscains venant parfois des tenants de l'ordre, soucieux de le faire revenir à sa pureté. Après la préface (par D. VANCE SMITH, pp. 1-6) qui rappelle le rôle du dédicataire dans l'étude de la littérature franciscaine, les contributions, au nombre de treize, présentées d'abord lors d'un colloque qui s'est tenu à l'université de Princeton en 2004, sont réparties en quatre sections: Franciscan Exegesis, Students and Scholars, Franciscan Critics and Critics of Franciscans, Franciscan Legacies.

Dans le cadre de la rassegna on retiendra plus particulièrement: William J. COURTENAY, Franciscan Learning: University Education and Biblical Exegesis, pp.55-64, sur le fonctionnement de la formation universitaire et ses liens avec la production écrite; Janet coleman, Using, Not Owning-Duties, Not Rights: The Consequences of Some Franciscan Perspectives on Politics, pp. 65-84, sur la spécificité de l'approche juridique de la situation humaine chez les franciscains, en particulier au XIve s. G. GELTNER, William of St. Amour's "De periculis novissimorum temporum": A False Start to Medieval Antifraternalism?, pp.105-118, sur la critique radicale formulée par Guillaume de Saint-Amour et l'influence qu'elle a exercée; Lester K. LITTLE, "Imitatio Francisci”: The Influence of Francis 
of Assisi on Late Medieval Religious Life, pp.195-218; William Chester JORDAN, Louis IX: Preaching to Franciscan and Dominican Brothers and Nuns, pp. 219-235, sur la question: saint Louis a-t-il prêché aux frères? L'index complète le volume. 